\title{
Rattan as a Craft Material of Community on the North Coast of Java (Rattan Craft Study in Teluk Wetan Jepara)
}

\author{
Alamsyah $^{1}$ \\ ${ }^{1}$ Lecture of Department of History, Faculty of Humanities, Diponegoro University, Semarang - Indonesia
}

\begin{abstract}
Rattan was the main raw material used in rattan craft in Teluk Wetan Jepara. This research uses historical methods namely heuristic, criticism, and interpretation. The results of this study show that the rattan could be made into various craft products such as parcel baskets, bags, chairs, tables, and etc. Rattan craft in Teluk Wetan involved local workers, craftsmen, and entrepreneurs. The products had been marketed on Java, out of Java island, Europe and America. The craft development was around 1972 and still developed rapidly to this day. Rattan craft was soft skills owned by Teluk Wetan community and had an impact on the local economy. The craft existence was supported by workers, craftsmen, and entrepreneurs, both who had small and large scale. The existence of workers, craftsmen, and entrepreneurs encouraged the craft to live and develop. The existence of rattan craft made the community's economic life of Teluk Wetan became dynamic as well as made this region became a craft center that recognized locally, regionally and nationally.
\end{abstract}

Keywords: Rattan; Raw Materials; Rattan Craft; North Coast; Teluk Wetan Jepara.

\section{Introduction}

Rattan is one of plants that naturally grow in primary and secondary forests, including in former shifting cultivation areas and shrubs. Rattan is classified as vine that requires a host plant for its growth process. This prickly palm species is found in tropics to subtropics area. The word rattan in Malay comes from the word "raut" which means peeling, skinning or smoothing. Rattan is forest product that has a potency to be developed as trade material, both for domestic needs and for export purposes [1].

Rattan is used as a craft material by people in Indonesia, including rattan craft in Teluk Wetan Jepara. With these rattans as the raw materials, various craft products can be made such as parcel baskets, bags, chairs, tables, and etc. Jepara which is an area of coastal community has a spirit of togetherness and entrepreneurship. This community is adaptive so they are able to form a system and cultural values which are acculturation of each component that forms its community structure [2]. The life of north coastal community in Central Java is creative pluralistic so that it forms creativity and innovation in the field of art carving crafts [3] and rattan craft which is located in Teluk Wetan village, Welahan sub-district, Jepara.

Rattan craft in Teluk Wetan involve around 990 craftsmen [4] and absorb about 4,665 labors [5]. This rattan craft is Jepara superior product owned by the community through a training process that is inherited from generation to generation. Rattan craft in Teluk Wetan has been existing before 1972. At that time the production process was still managed and made traditionally. Since 1972 it has been developed and assisted by Jepara Regency government. Through the establishment of the Rattan Craftsmen community, the efforts to develop these crafts were carried out. The Rattan Craftsmen Community was given education and training about innovative rattan craft production so that it had high selling value. All the community members mastered in weaving and processing rattan so that in the 1980s there were about 100 rattan craftsmen. In 2000, the production process of rattan craft had used machine [6]. Based on the background above, this article will explain rattan as a material for making community craft in Teluk Wetan Jepara.

\footnotetext{
${ }^{*}$ Corresponding author: alam mahir@yahoo.com
} 


\section{Method}

This study uses historical methods consisting of heuristics, criticism, interpretation, and historiography [7]. Heuristics is the process of finding primary and secondary sources [8]. The primary sources are obtained from observation activities, government or individual archives, observation activities' pictures, and interviews with businessmen of rattan handicraft. Craftsmen involved in rattan crafting are around 900 people. Interviews were conducted on 100 people involved in rattan crafts. The interviews about rattan crafts were carried out with the community involved in rattan crafts. Secondary sources are obtained from some works that are relevant to the research either from books, journals, and data from the Jepara statistical center, other literature. Secondary sources are obtained from libraries, personal collections, and internet. The available sources are then criticized and interpreted. The analysis results above are then connected and reconstructed into an article about rattan as a material for making craft by community in Teluk Wetan Jepara.

\section{Results and Discussion}

\subsection{Rattan as a Material for Making Craft}

Rattan is a non-timber forest product commodity that has a very big potency in Indonesia. In 1995, Indonesian rattan market share ranked first (75\%) as the world rattan producer. In 2010, the Indonesian rattan market share in the world rattan trade had reached $80 \%$. The high market share was mainly supported by the amount of rattan producing area in Indonesia, where $90 \%$ of rattan was produced from natural forest and the remaining $10 \%$ was gotten from rattan cultivation. From natural forests spread on Kalimantan, Sumatera, Sulawesi and Irian islands, Indonesia have a potency to produce 622.000 tons of dry rattan per year. The abundance of Indonesian rattan is a potential to be used as raw material for rattan craft because this craft production activity is labor intensive that absorbs a lot of labor [9]

Rattan is material for furniture. Products made of rattan like this can also be used in almost all aspects of human life such as house construction, house interiors, offices, bridges, baskets, mats, ropes, and etc. Rattan is a source of foreign exchange because Indonesia is the biggest rattan producing country in the world. Rattan is a material of home industry crafts so that it can be a livelihood source of the community [10]. Rattan as a material for making the craft has also been developed for a long time in Teluk Wetan since before 1972 .

\subsection{Creative Economy of Rattan Craft}

The creative economy is a set of (knowledge-based economic activities) that intensively uses creativity and innovation as its primary input to produce various value-added products and services. Creative economy has 3 dimensions, they are innovation and creativity dimension, technological capability dimension, and art and culture dimension [11]. One of the creative economic sub-sectors is crafts. Craft is a creative activity related to creation, production, and distribution of products that are made or produced by craftsmen starting from the initial design to the completion of the product. One of craft products is made from rattan. These craft products are generally only produced in small quantities, not in mass production, but in its development, this product can be made mass with a touch of machine technology [12].

\subsection{Rattan Craft Development in Teluk Wetan Jepara}

The rattan craft industry in Teluk Wetan has been developing since 1972. In that year, there were about 10 craftsmen. This craft development is quite rapid because based on BPS data in 2018, there were about 990 rattan craft entrepreneurs in Teluk Wetan. In 2016 , the industry had been able to absorb around 4,000 workers so almost $80 \%$ Teluk Wetan community worked in this sector [13]. The rattan craft industry in Teluk Wetan is dominated by homemade rattan craftsmen. At first, rattan crafts development was assisted by the government, but in recent year the rattan craft entrepreneurs have developed independently without government assistance anymore [14].

Table 1. Estimated Number of Craftsmen

\begin{tabular}{|c|c|c|}
\hline Number & Year & Number of Craftsmen \\
\hline 1 & 1972 & 10 \\
\hline 2 & 2018 & 990 \\
\hline
\end{tabular}

Source. Data Processed from Interview Results

The existence of rattan craft is supported by craftsmen whether they inherit the business or because of the environment that is a rattan crafts center, which encourages the emergence of new rattan craftsmen in this region. Most of the craftsmen start their businesses with initial capital about Rp. $1,000,000$ to Rp. Rp. 20.000.000,-. It is gotten from their personal savings and bank or cooperatives loans 
[15]. Bigger craftsmen use initial capital of around Rp. $\quad 100.000 .000,-$. And it is a loan from bank [16]. The workers number for small rattan crafts industry is between 1-15 [17]. Meanwhile, the workers number for big rattan craft industry is more than 30 workers [18].

The business management of small rattan craft industry is managed directly by the entrepreneurs or craftsmen, without assistance from others. The entrepreneurs or business owners take care of everything from raw material purchases, production, sales, finance, and worker recruitment [19]. The management of big rattan craft industry has been managed by several professional staff. The business owner only supervises the company [20]. Product marketing for small rattan craft industries is sent to several cities in Java and out of Java. The product is most often marketed in Semarang, Yogyakarta, Jakarta, Bali, Medan, and Surabaya [21]. The product of big rattan craft industry is marketed abroad, including those that sent to Europe and United States.

\subsection{Rattan Craft Product}

The products produced by small and large rattan crafts industries are different. The products of small rattan craft industry are such as plain parcel basket, colored parcel basket, white parcel basket, mixed color parcel basket, and rattan bag. The products of big rattan craft industry are in the form of furniture such as rattan chairs, mixed rattan chairs, and rattan tables.

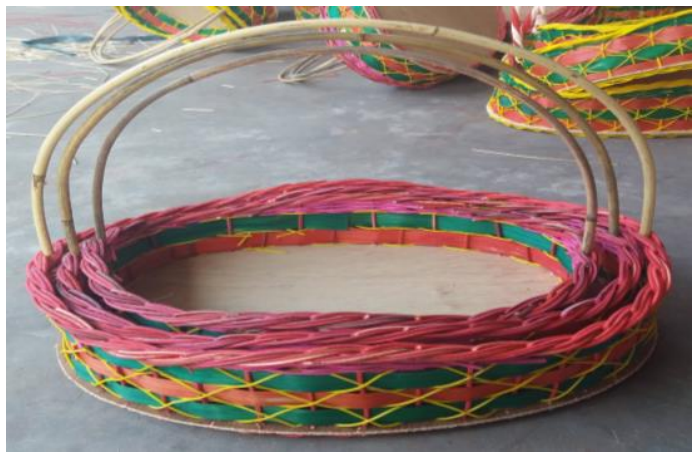

Source: Author's Documentation, May 2019

Fig. 1. Coloured Rattan Parcel Basket 1 set consists of 3 types of basket. Using textile dyes, Karjono's collection

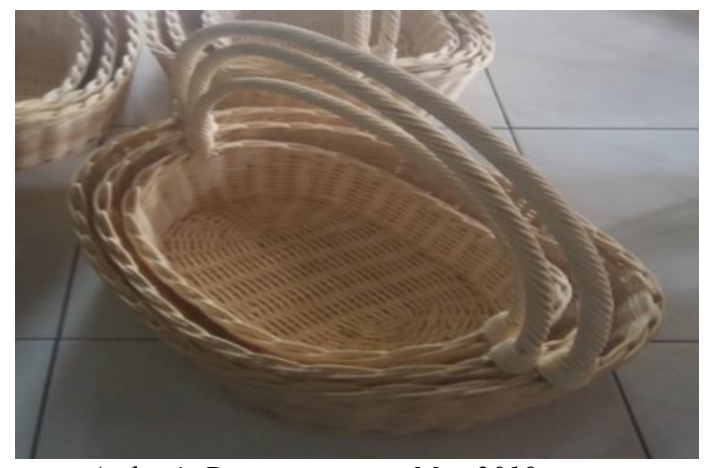

Source. Author's Documentation, May 2019

Fig. 2. Plain Rattan Parcel Basket 1 consists of 3 types of basket. Product of Taskan's Rattan Craft Industry.

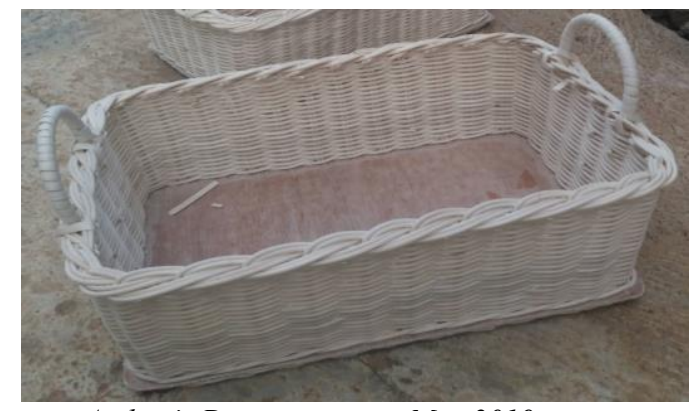

Source. Author's Documentation, May 2019

Fig. 3. White Rattan Parcel Basket with glass water as the dye. Product of Darwati's Rattan Craft Industry.

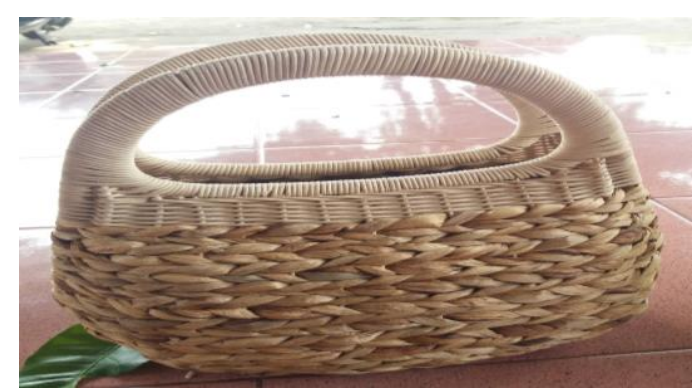

Source. Author's Documentation, May 2019

Fig. 4. Rattan Bags combined with Water Hyacinth. Product of Taskan's Rattan Craft Industry.

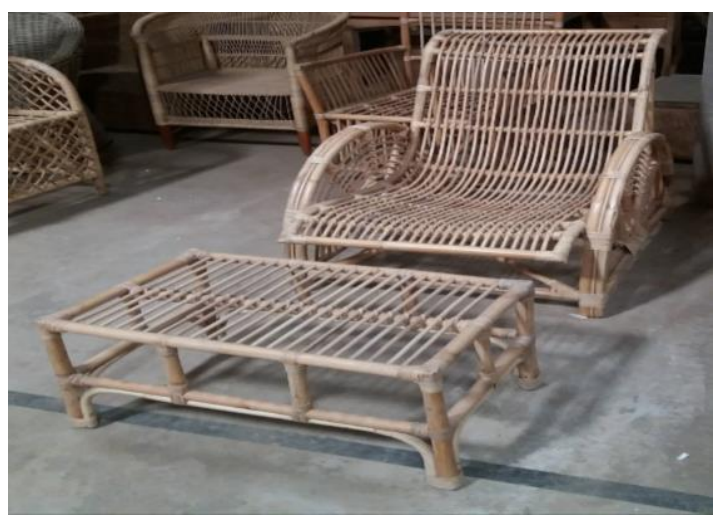

Source. Author's Documentation, May 2019

Fig. 5. Rattan chairs and tables for export. Product of Nurhadi's Rattan Craft Industry. 


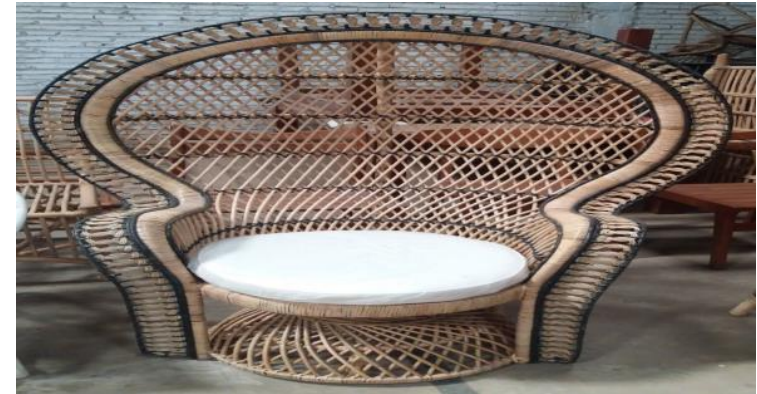

Source. Author's Documentation, May 2019

Fig. 6. Rattan lounge chairs for export, Nurhadi.

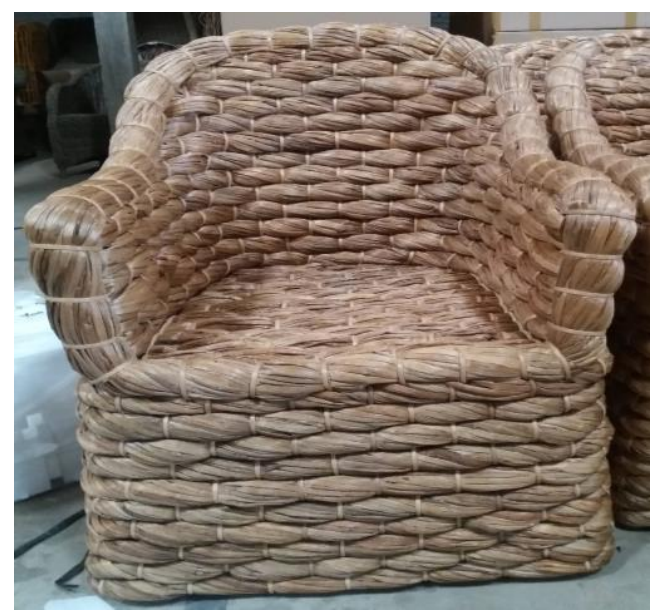

Source. Author's Documentation, May 2019

Fig. 7. Chairs use big rattan as the material of Nurhadi's Rattan Craft Industry.

\subsection{Rattan Craft Worker}

Rattan craft workers have had weaving skills since they were teens. Most workers are 30 years old and over, young people are rare to work in this industry because they prefer working in big factories (garment) [22]. Most workers in big and small rattan craft industry are temporary workers. The working time starts at 08.00 to 16.00 , with the breaking time at $12.00-13.00$. The workers at first are asked to work by craftsmen or entrepreneurs with Rp. $125.000,-/$ a week as the lowest wages and Rp. $500.000,-/$ a week as the highest wages [23]. The workers who weave rattan at home feel comfortable because it does not interfere with their house chores [24]. Mostly the workers' family give support to working in rattan craft industry [25]. But there are some workers' families who do not support to work in this industry because of the low wages [26].

\section{Conclusion}

Rattan as a material for making craft products has a good economic prospect for the community's economy. This has been proven by the existence of rattan craft in Teluk Wetan Jepara with its various types of products. This creative craft industry gives some contributions to the local community because they are involved as workers, craftsmen as well as entrepreneurs. Workers who involved in rattan crafts are daily workers and permanent workers. This craft is growing rapidly. In its development, Teluk Wetan has become a rattan craft center that is able to fulfill the rattan craft needs in big cities in Java and out of Java, it even has expanded abroad. With this research, it is seen that craftsmen and businessman need to strengthen their knowledge by utilizing the development of information technology 4.0, especially for product marketing

The research is funded by DIPA Diponegoro University in 2019 budget year

\section{References}

1. Jumiati, B. Hariyadi, P. Murni, Studi Etnobotani Rotan Sebagai Bahan Kerajinan Anyaman Pada Suku Anak Dalam (SAD) Di Dusun Senami, Desa Jebak, Kabupaten Batanghari, Jambi, Biospecies 5(1) (2012)

2. Wahyudin, Yudi, Sistem Sosial Ekonomi dan Budaya Masyarakat Pesisir, Bogor: Pusat Kajian Sumberdaya Pesisir dan Lautan Institut Pertanian Bogor (2003)

3. Alamsyah, The Ups and Downs of Wood Furniture Industry Center at the Nort Coast of Java Before and After Reformation Era: The Case of Jepara Furniture Center, Advance Science Letters 23(10) (2017)

4. Badan Pusat Statistik, Kecamatan Welahan Dalam Angka, (2018)

5. Badan Pusat Statistik, Kabupaten Jepara Dalam Angka (2016)

6. Interiew with Taskan, 14 Mei 2019.

7. Garraghan, Gilbert. A Guide to Historical Method. New York: Fordham University Press (1947)

8. Herlina, Nina. Metode Sejarah. Bandung: Satya Historika (2008)

9. A. Fariyanti, Dampak Kebijaksanaan Larangan Ekspor Rotan terhadap Pertumbuhan Industri dan Distribusi Rente Ekonomi di Indonesia, Tesis. Bogor: Program Pascasarjana, Institut Pertanian Bogor (1995)

10. D.M. Jasni, N. Supriana, Sari Hasil Penelitin Rotan. Departemen Kehutanan (2007)

11. Suboroto, Ekonomi Kreatif Di Masa Depan : Memperkuat Identitas Budaya Lokal Kabupaten Jepara, Prosiding Seminar \& 
Konferensi Nasional Manajemen Bisnis, UMK (241)

12. A.R. Sari, M.S.Ed, tt., Ekonomi Kreatif : Konsep, Peluang, dan Cara Memulai

13. Interview with Budi Santosa, 14 Mei 2019.

14. Interview with Taskan, 14 Mei 2019.

15. Interview with Muchson, 14 Mei 2019; Interview with Suhartoyo, 15 Mei 2019; Interview with Sunarji, 15 Mei 2019; Interview with Trisno, 16 Mei 2019.

16. Interview with Nurhadi, 16 Mei 2019.

17. Interview with Muchson, 14 Mei 2019; Interview with Darwati, 14 Mei 2019; Interview with Suhartoyo, 15 Mei 2019; Interview with Naskan, 15 Mei 2019; Interview with Karjono, 15 Mei 2019; Interview with Trisno, 16 Mei 2019.

18. Interview with Nurhadi, 16 Mei 2019.

19. Interview with Muchson, 14 Mei 2019; Interview with Darwati, 14 Mei 2019; Interview with Suhartoyo, 15 Mei 2019; Interview with Naskan, 15 Mei 2019; Interview with Karjono, 15 Mei 2019; Interview with Trisno, 16 Mei 2019.

20. Interview with Nurhadi, 16 Mei 2019.

21. Interview with Taskan, 14 Mei 2019; Interview with Muchson, 14 Mei 2019; Interview with Darwati, 14 Mei 2019; Interview with Naskan, 15 Mei 2019; Interview with Karjono, 15 Mei 2019; Interview with Trisno, 16 Mei 2019.

22. Interview with Suhartoyo, 15 Mei 2019.

23. Interview with Ali, 14 Mei 2019; Interview with Nur, 14 Mei 2019; Interview with Miatun, 15 Mei 2019; Interview with Munsarofah, 15 Mei 2019; Interview with Siti, 16 Mei 2019.

24. Interview with Ibu Miatun, 15 Mei 2019; Interview with Munsarofah, 15 Mei 2019; Interview with Sumaikah, 15 Mei 2019; Interview with Siti, 16 Mei 2019.

25. Interview with Ali, 14 Mei 2019; Interview with Nur, 14 Mei 2019; Interview with Miatun, 15 Mei 2019; Interview with Munsarofah, 15 Mei 2019; Interview with Siti, 16 Mei 2019.

26. Interview with Kasturi, 15 Mei 2019; Interview with Amin, 16 Mei 2019. 